\title{
Labyrinthe
}

2| 1999

Numéro 2

\section{Un prêté pour un rendu}

Jean-Louis Leutrat

\section{(2) OpenEdition}

Journals

Electronic version

URL: http://journals.openedition.org/labyrinthe/364

DOI: $10.4000 /$ labyrinthe.364

ISSN: 1950-6031

\section{Publisher}

Hermann

Printed version

Date of publication: 15 January 1999

Number of pages: 97-99

\section{Electronic reference}

Jean-Louis Leutrat, " Un prêté pour un rendu », Labyrinthe [Online], 2 | 1999, Online since 04 March 2005, connection on 03 May 2019. URL : http://journals.openedition.org/labyrinthe/364 ; DOI : $10.4000 /$ labyrinthe.364

This text was automatically generated on 3 May 2019.

Propriété intellectuelle 


\section{Un prêté pour un rendu}

Jean-Louis Leutrat 